\title{
„Biorę sobie ciebie za żonę/męża...” Co dzisiaj majq na myśli narzeczeni? - jesienne sympozjum Wydziału Prawa Kanonicznego UPJPII w Krakowie
}

\author{
DOI: http://dx.doi.org/10.15633/acan.3398
}

15 listopada 2018 roku w Auli Instytutu Teologicznego Księży Misjonarzy na krakowskim Stradomiu odbyło się coroczne sympozjum zorganizowane przez Wydział Prawa Kanonicznego Uniwersytetu Papieskiego Jana Pawła II. Problematyka tegorocznych referatów oscylowała wokół kanonicznego materialnego prawa małżeńskiego, a myśl przewodnia została określona w temacie „Biorę sobie ciebie za żonę/ męża...”. Co dzisiaj mają na myśli narzeczeni? Sesja naukowa wyraźnie wpisała się, poprzez poruszane zagadnienia - bliskie sercu i misji Patrona naszej uczelni, w obchodzoną w archidiecezji krakowskiej 40. rocznicę wyboru kard. Karola Wojtyły na Stolicę Piotrową.

Sympozjum zostało zainaugurowane przez dziekana Wydziału Prawa Kanonicznego ks. prof. dr. hab. Tomasza Rozkruta, który zaprosił przybyłych do wspólnej modlitwy, a następnie powitał dostojnych gości, prelegentów, obecnych na sali pracowników instytucji kościelnych z całej Polski, a także zgromadzoną publiczność. Ksiądz Profesor w swoim przemówieniu zwrócił uwagę na ważkość i aktualność poruszanej tematyki w kontekście posługi duszpasterskiej Kościoła. Powiedział, że celem refleksji naukowej w tej kwestii jest próba odpowiedzenia na dylematy, z jakimi zmagają się małżeństwa w obecnym świecie, aby pomóc współczesnym ludziom w odkryciu piękna rzeczywistości małżeńskiej, w której realizuje się nie tylko szczęście oraz satysfakcja samych małżonków, ale przede wszystkim ich wieczne zbawienie.

W dalszej kolejności głos zabrał abp prof. dr hab. Marek Jędraszewski, metropolita krakowski. Wielki Kanclerz Uniwersytetu Papieskiego Jana Pawła II dokonał uroczystego otwarcia obrad i w wygłoszonym słowie zwrócił uwagę na panującą w dzisiejszych czasach kulturę tymczasowości oraz płynności, w której coraz trudniej człowiekowi dokonać trwałego, a także ostatecznego wyboru, jakim niewątpliwie jest wstąpieniew związek małżeński. Zaznaczył, że powodem kryzysu rodziny, małżeństwa, ale również powołanych do kapłaństwa czy życia konsekrowanego jest to, że młodzi głęboko osadzeni we współczesnej mentalności uciekają od przeszłości i przyszłości na rzecz trwającej chwili, co negatywnie wpływa na podjęcie decyzji wymagających odpowiedzialności. Ksiądz Arcybiskup wyraził nadzieję, że konkluzje z obrad będą ważnym głosem w dyskusji nad tym, jak przygotować narzeczonych do owocnego przyjęcia i przeżywania sakramentu małżeństwa. 
Następnie słowo wprowadzające do zgromadzonych skierował prorektor Uniwersytetu Papieskiego Jana Pawła II ds. rozwoju i polityki kadrowej ks. dr hab. Antoni Świerczek, prof. UPJPII. Odwołując się do alokucji Benedykta XVI do Roty Rzymskiej wygłoszonej dnia 2 stycznia 2011 roku, a także posynodalnej adhortacji apostolskiej Amoris laetitia papieża Franciszka z 2015 roku, powiedział, że rolą Kościoła jest odpowiednia formacja narzeczonych, aby podjęta przez nich decyzja o zawarciu sakramentalnego małżeństwa była w pełni świadoma.

Pierwszą sesję moderował ks. prof. dr hab. Wojciech Góralski z Uniwersytetu Kardynała Stefana Wyszyńskiego w Warszawie, który podziękował za zaproszenie i pogratulował krakowskiemu środowisku kanonistów sumienności w cyklicznym organizowaniu sympozjów.

Pierwszy referat na temat $W$ co wierzy ochrzczony niewierzący, gdy zawiera małżeństwo? wygłosił ks. prof. dr hab. Ginter Dzierżon z Uniwersytetu Kardynała Stefana Wyszyńskiego. W swoim przedłożeniu zastanawiał się, w jakich przypadkach małżeństwo ochrzczonego niewierzącego nie będzie sakramentem, zaznaczającjednocześnie, że natura problemu jest delikatna, ponieważ dotyczy minimalnego poziomu wiary nupturienta, czyli kwestii niemożliwej do zweryfikowania w sposób prawny. Prelegent zauważył, że doktryna obecnie raczej skupia się na analizie przedmiotu konsensu, a więc czy nie zaistniało wykluczenie sakramentalnej godności małżeństwa. Argumentował, powołując się na jurysprudencję Roty Rzymskiej oraz posynodalną adhortację apostolską Familiaris consortio Jana Pawła II z 1981 roku, że wystarczająca u kontrahentów jest intencja do zawarcia małżeństwa naturalnego, a symulacja częściowa zachodzi jedynie, gdy wykluczenie sakramentalności przeważa nad wolą zawarcia małżeństwa. Ksiądz Profesor zwrócił także uwagę na małżeństwa mieszane, w których na mocy kan. 1125 Kodeksu prawa kanonicznego u strony katolickiej wymagany jest pewien poziom wiary, aby mogła wychować w niej swoje potomstwo. Konkludował, że na zadane w temacie pytanie nie można udzielić jednoznacznej odpowiedzi, gdy punktem odniesienia będzie element podmiotowy zgody. Jednak, jeśli za kryterium przyjmie się aspekt przedmiotowy konsensu, to narzeczeni, aby zawrzeć ważne małżeństwo powinni miećświadomość sakramentalnej godności małżeńskiej w taki sposób, w jaki widzi ją Kościół, co pozostaje w zgodności z wykładnią Międzynarodowej Komisji Teologicznej z 1977 roku.

Kolejnym prelegentem był ks. dr hab. h. c. Leszek Adamowicz z Katolickiego Uniwersytetu Lubelskiego, a temat jego odczytu brzmiał Jak przy spisywaniu protokołu przedmałżeńskiego sprawdzić, czy nupturient nie wyklucza nierozerwalności? Kanonista w swoich rozważaniach oparł się na instrukcji Konferencji Episkopatu Polski 
o przygotowaniu do zawarcia małżeństwa z 1986 roku i projekcie nowej regulacji w tej kwestii, która wciąż oczekuje na recognitio Stolicy Apostolskiej. Według obowiązujących przepisów duszpasterz ma poważny obowiązek zbadania znajomości nauki chrześcijańskiej u nupturientów, a także przeprowadzenia z każdym z nich rozmowy, aby uzyskać odpowiedzi wymagane w protokole przedślubnym. Przemawiający odniósł się do fragmentu posynodalnej adhortacji apostolskiej papieża Franciszka Amoris laetitia dotyczącego bezpośredniego przygotowania do małżeństwa i zaznaczył, że duchowny w czasie rozeznawania powinien domniemywać dobrą intencję narzeczonych, a według projektu nowych przepisów ponadto ma unikać sprawiania wrażenia, iż rozmowa jest zbieraniem dowodów na poczet ewentualnego kanonicznego procesu o stwierdzenie nieważności. Jako podsumowanie autor powiedział, że duchowny powinien przekazać narzeczonym, opartą na źródłach, naukę Kościoła dotyczącą nierozerwalności, zadać pytania przewidziane protokołem oraz zdiagnozować osobisty stosunek nupturientów do przymiotu sakramentalności - zaś jedynym powodem do odmówienia asystowania przy zawarciu małżeństwa może być wyraźne uzewnętrznienie złej woli czy pozytywnego aktu woli u badanych.

Ostatni referat w sesji pierwszej na temat Małżeństwo zawarte „z powodu ciąży”. W oczywisty sposób nieważne? wygłosił ks. dr hab. Piotr Steczkowski, prof. UR, który na wstępie przedstawił założenia procesu skróconego wprowadzonego przez motu proprio Mitis Iudex Dominus Iesus ojca świętego Franciszka z 2015 roku pod kątem pojęcia nieważności oczywistej (nullitas manifesta). Mówca stwierdził, że intencją wprowadzenia nowych regulacji w kanonicznym prawie procesowym nie było ustanowienie dodatkowych tytułów nieważności, dlatego katalogu przykładowych powodów wymienionych w art. 14 § 1 papieskiego dokumentu nie można uznać za wiążący. Ksiądz Profesor, odwołując się do doświadczeń Roty Rzymskiej, równocześnie zwrócił uwagę, że niechciana ciąża może stać się przyczyną symulacji całkowitej, wykluczenia istotnego przymiotu małżeństwa, podstępu, przymusu czy też bojaźni szacunkowej. Na zakończenie dodał, że nieplanowane dziecko wcale nie musi prowadzić do orzeczenia nieważności sakramentu małżeństwa, ale wręcz odwrotnie - do umocnienia relacji między przyszłymi rodzicami, ponieważ stan błogosławiony przyjęty spokojnie to świadectwo realizacji istotnych obowiązków małżeńskich.

Po zaprezentowaniu wszystkich referatów w tej sesji jej przewodniczący rozpoczął dyskusję, podczas której publiczność miała możliwość zadawania pytań prelegentom. Pytania dotyczyły różnych sytuacji związanych z niewiarą nupturientów, 
lecz najbardziej żarliwą polemikę wywołała sprawa potencjalnego wyrażenia zgody na zawarcie małżeństwa przez osoby a priori dopuszczające separację czy rozwód.

Drugą sesję, która rozpoczęła się po półgodzinnej przerwie, prowadził ks. dr Michał Grochowina - absolwent Wydziału Prawa Kanonicznego Uniwersytetu Papieskiego Jana Pawła II, oficjał Sądu Biskupiego w Sandomierzu.

Jako pierwszy referat Zawarcie małżeństwa z przyczyny całkowicie obcej życiu małżeńskiemu zaprezentował ks. prof. dr hab. Grzegorz Leszczyński z Uniwersytetu Łódzkiego. Na wstępie Ksiądz Profesor, opierając się na kanonach 1055 i 1056 Kodeksu prawa kanonicznego, wyłożył katolicką wizję małżeństwa, ze szczególnym uwzględnieniem aspektu wspólnotowego nie tylko w sferze seksualnej, ale i w wymiarze przeżywania codziennych problemów. Powiedział, że przyczyny właściwe do zawarcia małżeństwa to przede wszystkim zgodność świadomości nupturientów z rzeczywistą koncepcją sakramentu. Prelegent podkreślił, że współczesna kultura określana jako wolnościowa nie sprzyja zachowaniu jedności, wierności i nierozerwalności w relacji małżeńskiej, a jako tytułowe przyczyny obce życiu małżeńskiemu wymienił przede wszystkim wykluczenie istotnego przymiotu małżeństwa, symulację całkowitą, gdzie słowa wypowiadane przez kontrahenta nie odpowiadają jego wewnętrznej intencji, zaburzenia osobowości (w szczególności psychoseksualne) i wszelkiego rodzaju determinacje woli.

Ostatnimi prelegentami byli dr Karol Zawiślak i ks. dr Marcin Wolczko - pracownicy Wydziału Prawa Kanonicznego Uniwersytetu Papieskiego Jana Pawła II w Krakowie, którzy wygłosili odczyt na temat "Jak się nam nie uda, to się rozejdziemy”. Intercyza przedślubna a wykluczenie nierozerwalności małżeństwa. Pierwszy z nich skupił się na zaprezentowaniu instytucji intercyzy w prawie cywilnym. Stwierdził, że polski ustawodawca preferuje spójność majątkową małżonków, jednak dopuszcza zawarcie przez nich (uprzednio względem małżeństwa) umowy wyłączającej wspólnotę majątkową. Pan Doktor zauważył, że zawarcie tego rodzaju porozumienia niekoniecznie musi prowadzić do rozstania się małżonków, ponieważ nie zwalnia ono męża i żony z dbania o dobro rodziny oraz jej utrzymywania. Ponadto intercyza może być korzystnym rozwiązaniem, jeśli małżonkowie prowadzą własne działalności gospodarcze i chcą zachować sprawny zarząd nad interesami. Drugi z mówców - ks. dr Marcin Wolczko przedstawił wpływ umowy wyłączającej wspólnotę majątkową na ważność małżeństwa. W tym celu odniósł się do trzech aspektów tworzących przymiot nierozerwalności sensu largo - stabilności (brak charakteru epizodycznego), trwałości (do śmierci) oraz nierozerwalności sensu stricto (przeświadczenie, że żadna siła nie jest w stanie rozwiązać węzła). Powołując 
się na orzeczenie Kongregacji ds. Kultu Bożego i Dyscypliny Sakramentów, która nakazała Konferencji Episkopatu Włoch modyfikację protokołu przedślubnego, tak aby narzeczeni mogli złożyć deklarację o intercyzie, wyjaśnił neutralne stanowisko Kościoła względem omawianej instytucji prawa cywilnego. Ksiądz Doktor konkludował, że fakt podpisania intercyzy przez małżonków nie stanowi istotnego argumentu czy dowodu podczas procesu o stwierdzenie nieważności małżeństwa, a także wcale nie musi świadczyć o wykluczeniu przez nich nierozerwalności.

Sesja druga zakończyła się dyskusją, w czasie której zadano kilka pytań dotyczących symulacji, ze szczególnym uwzględnieniem okoliczności oraz przyczyn wskazanego tytułu nieważności.

Po zakończeniu dyskusji tradycyjnego podsumowania listopadowego sympozjum w Krakowie dokonał dziekan Wydziału Prawa Kanonicznego Uniwersytetu Papieskiego Jana Pawła II, który podkreślił, że prawo, próbując znaleźć jak najlepsze rozwiązania, nigdy nie nadąża za zmieniającą się rzeczywistością. Zwrócił uwagę na powszechną w dzisiejszych czasach kulturę fragmentu, która wpływa również na rodzinę, a także zachęcił do dalszego podejmowania trudu całościowego spojrzenia na sakrament małżeństwa.

Wypada wspomnieć, że w sympozjum brał udział ks. prof. dr hab. Jan Maciej Dyduch - wieloletni wykładowca prawa kanonicznego, pierwszy rektor Uniwersytetu Papieskiego Jana Pawła II, twórca Instytutu Prawa Kanonicznego oraz kierownik Katedry Prawa Osobowego i Ustroju Kościoła na Wydziale Prawa Kanonicznego Uniwersytetu Papieskiego Jana Pawła II, który zmarł 17 listopada 2018 roku. Niestrudzoną obecność Księdza Profesora można śmiało potraktować jako swoiste pożegnanie ze środowiskiem naukowym i ukochaną dyscypliną.

Mateusz Sajkowski 